\title{
Life Beyond Cancer
}

Who am I to write on oncology? And that too in a medical journal? I am not a writer, not even a science graduate. Then why?

Maybe because mine is a story of an ordinary person, now leading an extraordinary life.

I did not chose this life, did not want it the way it played out for most of the past decade. We still made the best of it.

It is thanks to science, research, and developments in oncology and things beyond direct scientific evidence that I am here today. Things such as fate, luck, faith, hope, gratitude, resilience, and fortitude.

Till 2010, I had a perfectly nice middle-class life of an urban Indian. 2010 started as Annus Mirabelis as my son was admitted in some of the most prestigious schools of the country, I had just accepted a fantastic job, my husband's career was going well, and everyone around me was happy and healthy. Life was as good as it could be.

It is said that "Life is made up of small moments and just one such moment can change your life forever." For me, that life-changing moment came in June 2010.

In the last 2 days of a 4 weeks' vacation, I suddenly had bloating of my stomach, like that in a full-term pregnancy. Assuming that it was some stomach bug, I took basic antacids and tried the proven home remedies, till we reached back home. As the painless discomfort was too much, we went to a hospital the same evening, for a sonography.

It still sends shivers down my spine when I recollect that fateful Sunday evening when I was told that the bloating was due to malignancy or in common parlance, cancer.

My initial reaction was, Why me? Will I live? What will happen to my 5 year old? I am far too young to be having this terminal illness. Even if it was my destiny, could this not have come to me later in life? I who never hurt anybody, have a healthy lifestyle, and have no vices! WHY? How can God be so cruel?

A sense of gloom and foreboding descended upon me. LIFE which we all take for granted had suddenly became the most important thing for me. I wanted to survive! Just survive!

The Divya who was always known for her smile, had stopped smiling. I was scared. Scared of the unknown. I did not know how to deal with the situation and even before I could come to terms with it, my treatment had started.

I was put on a very aggressive and novel form of treatment which involved weekly doses of Chemotherapy. One session a week, every week for 9 weeks. Then, possibly a major surgery and then 9 more weeks of chemotherapy. All these, with no clue of will it work? Will I be able to sustain? Will I ever recover? Will I have a normal life?

While I got reconciled to the impeding major restrictions of the treatment regimen and its side effects, it was the restrictions on small day-to-day things that really hit me hard. Restrictions on doing daily chores, meeting family and friends, eating outside food and even hugging my son and my own mother, lest it gives me an infection and delays the treatment.

I did not look like a typical patient as I did not endure a lot of pain, thanks to the "quality-of-life" medicines. Yet, I was suffering. The dread of the $\mathrm{C}$ word was far more than the actual pain. The first time when a big bunch of hair came off, I was crestfallen. I put on a brave face before others. I even used to sleep with my wig on so that my little one doesn't see my bald head. Yet, life seemed to be slipping out of my hands.

One of the toughest challenges was dealing with the feelings of pity, sympathy, and resigned to fate. They used to take away my hope, like the death eaters from Azkaban.

Finally, in December 2010, my disease went in complete remission. I could breathe again.

Stage 4 ovarian cancer patient, if cured, has a very high chance of a relapse within 12 months and almost $100 \%$ chance within 24 months. My $1^{\text {st }}$ relapse was in September 2012. Like the terminator, the disease was back.

I was devastated. Why me again? I have already gone through hell and have emerged out battered and bruised. Then why?

The challenges in every relapse are many. From weakness and mood swings to hair loss and physical appearance, to just the sheer fatigue of the regime.

In between relapses [Figure 1], as normal life resumes, I have volunteered a couple of times to give back to the society. The most recent one being teaching in a blind school for girls. It was awe inspiring to see my girl students dealing with their daily life.

People often ask me how I deal with all these. Sometimes even I wonder how?

One thing which has seen me through so far is faith. If not my own occasionally dwindling faith then the faith of my well-wishers, faith on my doctors.

Initially, we were apprehensive about going to a government hospital, the Tata Memorial Hospital (TMH), at Mumbai. 


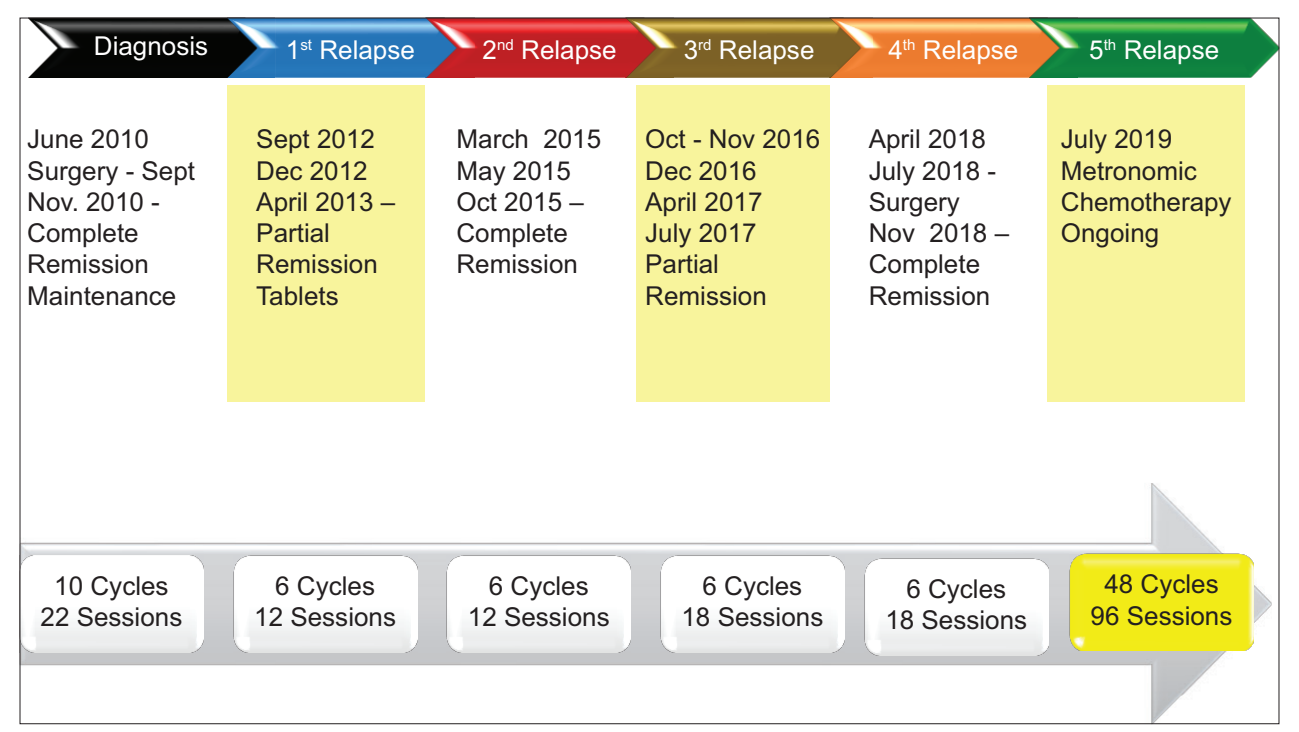

Figure 1: My journey is a manifestation of your efforts

The sheer number of people, the time it would take to get anything done, and the queues everywhere, were all tough to fathom. Will the doctors have time to talk to us? Will they really care about me, with the sheer numbers they handle? Are the hospital infrastructure, treatment facilities, and the medicines they prescribe are of world class?

Over the years, we have seen massive patient-focused improvements. Greater information availability with simple electronic medical records, automated token-based queues for blood tests, medicines, and the clarity of waiting period for scans have all made life far more simple, organized, and less stressful for everyone.

More physical space also means far-easier private day care for chemotherapy and better waiting areas in the outpatient departments. I don't like waiting on the roadside footpaths at 6:30 a.m. and not in the hospital premises when we used to come for chemotherapy. Hopefully, that too has now been resolved now.

Today, I can say that what has worked really well for me is not just the world-class skills of my doctors but also that smile my doctors greet me with, every time. Even with the sheer volumes of patients they handle every day, their patience to hear me out and the soft yet firm tone and words when I am being unreasonable are really heart warming. My doctor's calm demeanor, bubbly enthusiasm, and positivity, even when the reports seem to show things being dark and bleak, give me that courage and the boost, to go through the grind one more time.

Every little bit counts: the care and pep talk of the sisters at the TMH, the words of comfort of the mausis and the ward boys, and the patience and diligence of the secretaries and the office staff.

I feel blessed and humbled to see the sheer dedication of all the doctors and support staff at TMH and admire their patience and motivation levels to keep going, with such a high volume of anxious, forlorn, and at times agitated patients and their attendants.

Cancer treatment is a battle of attrition, and the unending support of my family and friends is one of the most important factors in my coping up, during and between treatments. Their adjustments to make me feel normal, rekindle my spirits and help me look beyond the current situation.

I am now at peace with myself. I have now learned to live life, one sunshine at a time Appendix 1.

After all, cancer is just a few thousand cells from the trillions of cells in my body that have gone rogue that need to be addressed.

I have also realized that God gives His toughest battles to His strongest soldiers.

In conclusion, these are my key learning:

\section{There is NO WONDER CURE}

Good things come to those who believe, better things come to those who are patient, and the best things come to those who don't give up

2. Everything comes at a cost and takes its toll. Grin it and bear it

Life consists not in holding good cards, but in playing those cards we hold, well

3. Find a purpose and passion in life.

For example, apart from the informal counseling we do to cancer patients and caregivers, we are now investing our life savings in setting up a world-class medicine testing lab and later, a tumor lab.

Oh yes, most important, I no longer yearn for pre-June 2010 life.

Do not regret growing older; it is a privilege denied to many. 


\section{Financial support and sponsorship}

Nil.

\section{Conflicts of interest}

There are no conflicts of interest.

\section{Divya Mathur}

Address for correspondence: Mrs. Divya Mathur, 9 Hari Niwas, 52 C Road, Marine Drive, Churchgate, Mumbai - 400 020, Maharashtra, India. E-mail:divyaambujmathur@gmail.com

Submitted: 12-May-2020

Revised: 01-Jun-2020

Accepted: 04-Aug-2020

Published: 31-Dec-2020
This is an open access journal, and articles are distributed under the terms of the Creative Commons Attribution-NonCommercial-ShareAlike 4.0 License, which allows others to remix, tweak, and build upon the work non-commercially, as long as appropriate credit is given and the new creations are licensed under the identical terms.

\begin{tabular}{|l|l|}
\hline \multicolumn{2}{|c|}{ Access this article online } \\
\hline Quick Response Code: & Website: \\
\hline & www.ijmpo.org \\
\cline { 2 - 2 } & DOl: \\
\hline
\end{tabular}

How to cite this article: Mathur D. Life beyond cancer. Indian J Med Paediatr Oncol 2020;41:895-8. 


\section{Appendix}

\section{Appendix 1}

1. You may read more on www.unfoldinglife.org.

2. And watch the TEDx talk on Life With and Beyond Cancer | Divya Mathur | TEDxVivekanandSchool at https:// www.youtube.com/watch?reload $=9 \& \mathrm{v}=$ AyKpnLlWLi4. 